
mondiales : la Révolution française

\title{
A gaze on the linguistic geography of the Napoleonic Italy through the letters of Jacques Boucher de Perthes
}

\section{Elisa Baccini}

\section{OpenEdition}

\section{Journals}

Electronic version

URL: https://journals.openedition.org/geohist/1277

DOI: $10.4000 /$ geohist. 1277

ISSN: 2264-2617

Publisher

Association française de la Revue de géographie historique

\section{Electronic reference}

Elisa Baccini, "A gaze on the linguistic geography of the Napoleonic Italy through the letters of Jacques Boucher de Perthes", Revue de géographie historique [Online], 13 | 2018, Online since 20 November 2018, connection on 12 June 2021. URL: http://journals.openedition.org/geohist/1277 ; DOI: https://doi.org/10.4000/geohist.1277

This text was automatically generated on 12 June 2021 .

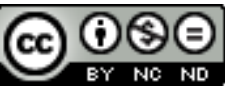

$\mathrm{Ce}(\mathrm{tte})$ œuvre est mise à disposition selon les termes de la Licence Creative Commons Attribution -

Pas d'Utilisation Commerciale - Pas de Modification 4.0 International. 


\title{
A gaze on the linguistic geography of the Napoleonic Italy through the letters of Jacques Boucher de Perthes
}

\author{
Elisa Baccini
}

1 The territorial expansion of the First Napoleonic Empire and the consequent relocation of Napoleonic soldiers and administrators had created a new conception of the geography of European space. This new geography brought together people of different nationalities and languages, all of them under imperial rule. Napoleon tried to impose his domination and eliminate these language differences by implementing a series of policies which had the goal to spread the French language and standardize language practices. Also in the Italian départements réunis were introduced these policies. In fact, there were the mandatory introduction of French in the exercise of administrative and judicial functions, the institution of the teaching of French language throughout the school system and the establishment of plays performed in French on the Italian main theatres. The hegemonic design on the French language, put into practice with these initiatives, had to clash with the local Italian realities in which dialects often prevailed over the national language. The French in service of the Emperor, once arrived in Italy, realized that regional dialects and languages were spoken in large sections of the population. In addition to this phenomenon, we must add the fact that frequently the French administrative division did not always coincide with the ancient territorial subdivisions (Broers, 2003), so for example in some Ligurian departments were amalgamated territories that belonged to ancient Piedmont, or even in some Piedmontese departments were present cantons of Aosta Valley, or finally in the two departments created by the former Roman states, regional territories with very different traditions were brought together. This arbitrary subdivision, not linked to territorial realities, led to departments in which there were more than one regional language or dialect. 
2 It was precisely this linguistic diversity that led the Napoleonic government to carry out an official investigation : the Bureau de statistique, in fact, undertook the project of reconstructing the linguistic geography of France, Italian departments included (Galimard, 1992; Ködel, 2012; McCain, 2018). It seems that the original idea came from the then Minister of the Interior, Jean-Baptiste de Champagny, who in 1806 entrusted the director of the Bureau de statistique, Charles Étienne Coquebert de Montbret, with this investigation on the spread of the French language in the Empire. The research was undertaken by Charles Étienne with his son Eugène, also employed in the same office, from 1806 to 1810, the year in which Eugène alone continued the work begun with his father until the closure of the Bureau de Statistique in 1812[i].

The purpose of the investigation was to trace the boundaries of the territories where French language was spoken, but also the geographical limits of those parts of the Empire where the mother tongue was not French, but German, Italian, Flemish, Breton and Basque. It is immediately obvious how much this effort to locate linguistic diversity in geographical space could have been useful for administrative purposes. However, what was a long and complex project did not have the desired effect on the imperial government, which decided to close the investigation in subject, but also on the Bureau de Statistique itself. Nevertheless, the documentation and data that emerged from this enquiry were numerous and advantageous in the sense of a first real effort to quantify the linguistic diversity of France.

4 The Coqueberts de Montbret had in addition the objective of identifying the " principaux points qui circonscrivent à peu près le territoire qu'occupe chaque dialecte secondaire de ces divers langages principaux»[ii]. In general, the picture that emerged, even in some areas of ancient France, was that a certain territory corresponded to an official mother tongue (which could be for example French, Italian or German), but that in reality the dialects had the widest spread. However, there is a fundamental difference between the data concerning the old French departments and the new Italian departments: in the latter case, in fact the main interest was to know the number of those who speak a specific language in a given territory and not only the dialectal geography of a region, as in the case of the French regions (Ködel, 2012).

5 The attention to the quantitative data, in the territories au de-là des Alpes, is very significant and can lead us to suppose that the government wanted to know some statistical data to undertake concrete political initiatives on the italian conquered territories. Besides the different search criteria between the imperial departments in France and the territories conquered outside it, the testimonies describing the linguistic habits in the departments are very significant. In many cases the prefects of the departments involved in the survey affirmed to a Coquebert who wondered whether or not dialects were spoken, that in reality the dialects were the real "languages" in use, in spite of Italian/Tuscan, which was also denied by people "bièn élevées", who despite reading it regularly, did not speak it except with pain and incorrectly[iii]. The ignorance of the Coqueberts de Montbret about the presence of dialects in the Italian departments coincided with that of the French officials who, sent to the new Italian territories, were faced with unexpected linguistic habits. Therefore, it is possible to assume that for these officials the real linguistic competitor of the French was not so much the Italian, as the local dialect of the department in which they had taken service. 


\section{The path of Jacques Boucher de Perthes and the letters from Italy}

Unfortunately, it is difficult to access documents that record oral practices, which is why the investigation of the Coqueberts is a valuable source for the time. In such a context of lack of sources, the epistolary of Jacques Boucher de Perthes can be precious, because his descriptions of the customs offices, but also of the Italian society of that time, are useful to reconstruct a small but fundamental part of the oral habits of Italy of the first years of the nineteenth century. Jacques Boucher de Perthes is considered one of the founders of the prehistoric sciences on which he carried researches in parallel to his career of literate and employee in the French customs[iv]. It is interesting that the beginning of his career in customs coincided with the foundation of the First Napoleonic Empire and it was in those years (precisely 1805) that he was sent to Italy, when he was only 17 years old, to serve in the customs of the city of Genoa, which had been that year annexed to France. Boucher de Perthes was in Genoa from 1805 to 1808, then in Livorno from 1808 to 1810 and finally in Foligno from 1810 to 1811. During his Italian stay he sent several letters to his family and other acquaintances, many of which narrated the linguistic practices of the populations of the territories where he worked. These letters were collected by him and published, with the correspondence of his entire life, in a work called Sous dix rois[v].

It is important, however, to make a observation on these letters. Boucher's correspondence was published in eight volumes from 1863 to 1868, therefore about sixty years after the employment in the imperial customs in Italy. They were surely the result of a hard revision for which there could be some problems of reliability. Regarding, however, the experiences described by Boucher about the linguistic geography of the departments visited by him, we cannot consider them not corresponding to the truth, or at least to corresponding to the impression that Boucher actually had when he lived in those territories. For what reason, in fact, the elderly Boucher would have altered the letters of the youth in those parts where he narrated the perception of the linguistic practices of the visited cities? There would be no valid explanations to these alterations, for which, with the due precautions regarding this source, I consider these letters valid for my investigation[vi].

Revue de géographie historique, 13 | 2018 


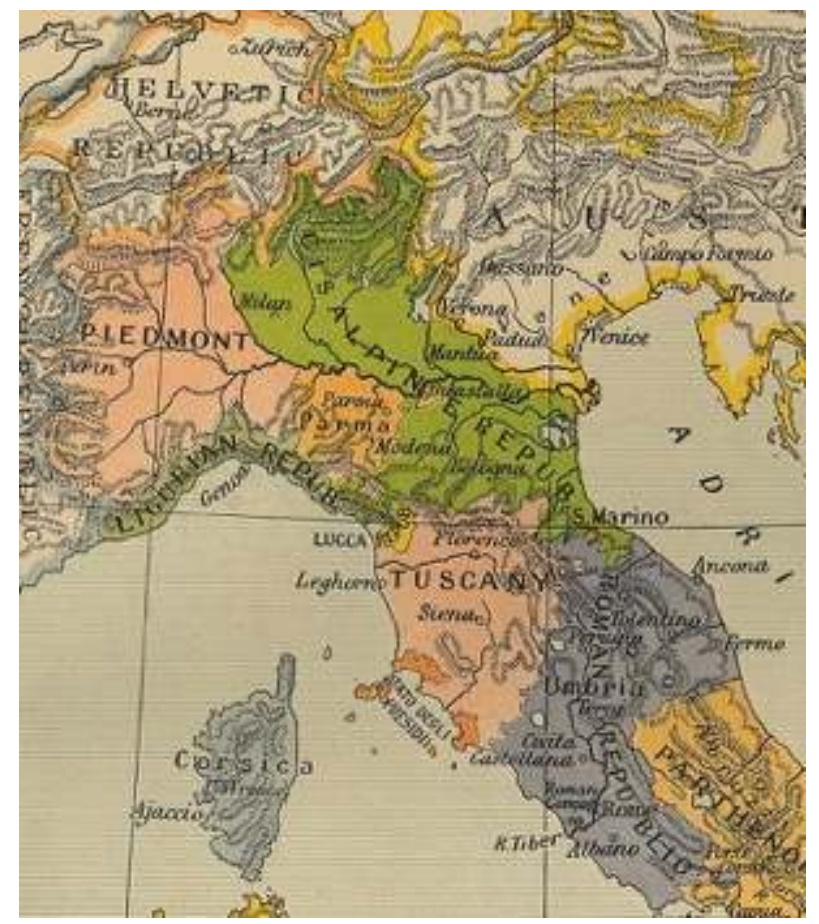

\section{A. Ligurian dialects and Italian language}

Many sources of the time, as in the exchanges of letters of Coquebert de Montbret, report the consideration that the French administrators were not aware of the real spread of dialects in Italy. Just these considerations are the first that Boucher sent to the parents once arrived in Genoa. In one of the first letters sent (25 September 1805) he describes to his mother a particular episode, which had seen him experiencing how was wide the spread of dialects:

«Il faut que je vous raconte ma première conversation dans notre petit port dont j'ai oublié le nom. Elle avait un motif sérieux : c'était de dîner. A peine débarqué, je me dirigeai, d'après l'indication de l'équipage, vers une espèce de cabaret décoré du titre d'hostellerie, et je dis à l'hôte de me procurer du pain frais.- Ah!signor, me répondit$\mathrm{il}$, in questo paese pane non è, ma se voleté cipolle [in this town there is not bred, but if you want onions].- Alors je lui demandai de la viande.- Ah! signor, me dit-il, carne non è in questo paese, ma se volete cipolle [in this town there is not meat, but if you want onions].Je lui demandai du poisson.-Ah! signor, s'écria-t-il plus piteusement encore, pesce non è in questo paese, ma se volete cipolle sono stupende [there is not fish in this town, but id you want onions].- Alors je lui demandai ce qu'il voulait dire par ses éternelles cipolle. - Ah! signor, cipolle veut dire cipolle.

Telle fut la réponse que j'en pu tirer. On fit venir un ancien perruquier qui avait voyagé en France ; il me dit : I francesi chiamano questo OGNON [th Frech call it ognon]. Bref, à l'aspect de la chose, je vis d'ici le cipolle étaient des ognons ; [...] Ce que j'ai compris par ma conversation au sujet des cipolle, c'est que l'italien de France n'est pas celui d'Italie où chaque province, m'a-t-on dit, a son patois. Déjà je sais que Gênes a le sien » [vii].

11 Boucher had come in contact with the Italian dialects as soon as disembarked in Genoa. His previous knowledge of Italian language had not made it any easier for him to have a 
simple conversation in which an innkeeper offered him an onion-based meal. This first experience with the Genoese dialect would be repeated just as strongly again in the days following his arrival, as he described to his father in a letter of 6 October 1805 in which he confessed to him: "Vous aurez peine à croire qu'à Gênes on ne parle que peu ou point l'italien, même dans les meilleures maisons; et le génois est à l'italien ce que le provençal est au français »[viii]. As the prefects had testified to Coquebert, the dialect was spoken by the whole population, even in socially elevated families. Also interesting was the parallel between the Genoese and the Provençal that Boucher made to his father to make him understand the linguistic context. However, Boucher still didn't realize how wide was the diversification and diffusion of the dialects, because these changed also radically from city to city. Boucher comprehended this fact during a visit to Chiavari, the chief town of another department, that of the Apennines, but which was a little more than 30 kilometers from Genoa. In Chiavari Boucher noted that, as in Genoa, also the notable people, «ne parlent pas français et, pour la plupart, pas italien, pas même génois, mais chiavarien, le plus étrange jargon qui soit au monde »[ix]. Perhaps it was a bit risky to declare that the Chiavarese dialect was the strangest jargon in the world, but this did not delete Boucher's awareness of the Italian dialectal diversity. Also in the customs offices Boucher negotiated daily with many different people, but it was not always possible to use the French or the Italian (sure still lacking in Boucher). We have seen that also in the high society of Genoa many spoke the local dialect, consequently Boucher was discouraged in this context in which he did not speak French, but he did not improve his Italian either:

12 «Il faut pourtant que quelqu'un m'écrive, car j'oublie le français sans apprendre à parler une autre langue, et il pourra se faire qu'un beau matin, en me réveillant, je me trouve muet. Je croyais savoir l'italien avant de venir ici ; mais depuis que j'y suis, je m'aperçois que je ne m'en doutais pas. L'autre jour, je me trouvais, dans un diner, à côté d'une dame, Génoise pur-sang et qui, en cette qualité, déteste beaucoup l'empereur et pas mal ses sujets. Elle s'amusait à m'agacer en disant tout le mal possible des Français qu'elle traitait de perfidi, traditori, etc., etc. Moi, je défendais la patrie, et pour l'amadouer, je dis d'une voix séduisante : Ah! signora vi adoro mio cor è sempre tuo [oh, my lady I adore you, my heart is always yours]. Vraiment la phrase était touchante. Deux fois elle me regarda. Et je ne me sentais plus d'aise, lorsqu'elle me dit :Che dica? lo non so parlar franzese [What are you saying? I cannot speak French] »[x].

Episodes like this, that brighten also the ironic side of the experience of Boucher de Perthes, underline many details of his lived. It emerges, in fact, that the previous knowledge that Boucher had of the Italian, reason perhaps that had contributed to its sending in Italy, had turned out useless to the communication with the Genoese. Even the pure Genoese blood had exchanged the Italian words of Boucher for French. Boucher confessed to being afraid to wake up one morning mute, because in Genoa he did not speak French, but not even Italian. His interlocutors from France often write him asking for information on the Italian language, but Boucher could only answer:

"Vous me parlez della bella lingua italiana. Il n'en est pas question ici ; on parle génois, ou bien français lorsque le vent tourne à la France, car notre santé dépend du gain ou de la perte d'une bataille. Quant à l'italien, néant ; la langue du Tasse n'est pas même comprise du peuple. Les tragédies d'Alfieri, que jouait cet automne une très-bonne troupe, ont été prises par quelques Liguriens pur-sang, qui ne voient dans l'italien que 
du génois corrompu, pour des comédies françaises. Quelle satisfaction pour Alfieri, s'il vivait encore !»[xi].

Here emerges a certain exasperation: Italian language was totally neglected in Genoa, to the point that some Genoese "pure-sang" exchanged the tragedies of Vittorio Alfieri for French comedies, as the lady recently seen had mistaken the Italian of Boucher for French. The Genoese dialect was very different from the pure Italian. The concept of purity of Italian, which characterized the discourse on language since the first Italian linguists of the fourteenth century, will be very dear to the French in general, and also to Boucher, who writes on several occasions this notion. Referring to the fact that he had forgotten his mother tongue, he wrote the he had taken « les manières, les formes, les tournures de phrase des habitants du pays. Bientôt je ferai comme eux, ne parlant purement aucune langue. Il convient qu'au moins, puisque je n'ai appris ni le grec ni le latin, je sache le français »[xii]. Even on a trip to Sarzana, a Ligurian town on the border with Tuscany, Boucher would have made similar considerations, after a brief description of the city:

"Sarzana est un des points extrêmes de la France nouvelle. Sarzana, petite ville assez jolie, est fort bien habitée. Je ne sais si les demoiselles nous y prennent pour des enfants de Satan : au seul nom de Français, elles se sauvent en faisant le signe de la croix. Il ne reste que les vieilles pour nous faire la grimace. [...] Ici, le génois n'est plus la langue usuelle ; l'italien devient plus pur : on sent qu'on approche de la Toscane $»[$ xiii].

Boucher perceived that the closer one got to Tuscany, the purer the language became, referring to the traditional conception of the Italian based on the Tuscan, fruit of centuries of debates on which Italian was the purest one. I must add that on 9 April 1809 Napoleon granted the inhabitants of Tuscany the privilege to use the Italian language in conjunction with French in public acts precisely because of the purity of the Tuscan language. At that time the privilege granted was the only one in the whole Empire and was motivated by the purity and prestige of Italian, as well as by the propensity for letters of Tuscans. Only after this concession would it have been given also to the Roman departments, for which it could still hold the motivation of prestige and literary glories. However, when this concession was extended also to the new departments of Central Europe, it could not be justified there by the literary qualities widespread among the population. In this case it can be said that Napoleon's policy was to pragmatically embrace the needs of the local population at the expense of imperial cultural policies. Returning to Boucher, he would have been transferred to Tuscany a few months after its annexation to the Empire as a vérificateur of the customs of Livorno, a strategic port city for Napoleon's naval operations.

\section{B. Language practises in Livorno}

17 As we have mentioned, from the linguistic point of view in Tuscany the situation was different. Boucher arrived in Livorno, having received the notification of his appointment the 20 October 1808. In Tuscany, before the Napoleonic decree granting the use of Italian, the imperial government had tried to get engrained itself from local population by favouring it in public appointments. Also Boucher would have observed this fact, which had put at risk his nomination: «Il paraît qu'une lutte s'est engagée à Florence entre M. de Sussy [director of the Tuscan customs] qui voudrait n'avoir pour employés que des Français, et la junte [the Giunta Straordinaria di Toscana] qui ne veut 
entendre parler que de Toscans. Si la junta l'emporte, il faudra rester [in Genoa][xiv]». Finally, however, the appointment had taken place, and from November 1808 to March 1810 Boucher remained in Livorno, sending his impressions to family and friends, with interesting reflections on the language spoken in Livorno :

"Le mélange des étrangers fait qu'on ne parle pas ici un italien aussi pur qu'à Florence et à Pise, mais pourtant les gens du peuple s'expriment moins mal qu'en Ligurie. Ils ont des abréviatifs ou des diminutifs qu'ils appliquent aux noms. L'autre jour, une femme de chambre à qui je demandais si ses maîtres étaient sortis, me répondait: La madre, il padre, il Joanino sono sortiti. Le Joanino était l'enfant. J'entendais ce même petit garçon varier le nom de M. Turc d'Aubigny de dix manières, et selon qu'il était de bonne ou de mauvaise humeur contre lui; il l'appelait Turco, Turchino, Turchetto, Turchinetto, Turcone, Turcaccio, etc. Ce savant compositeur de mots n'a pas cinq ans. Pippo, Checco, Checca, Chechina, sont les diminutifs de Philippe, François, Françoise»[xv].

Boucher noted that the harbour nature of the city had influenced the language, less pure than in cities visited many times by Boucher like Pisa and Florence, cities devoted for centuries to letters and the arts and venues of important centres of higher education. Boucher was then impressed by the variety of diminutives and nicknames used in Livorno, which is however a general feature in the Tuscan colloquial. Although the Livorno language was not pure, at least Boucher recognized that the people of the city expressed themselves better than in Liguria. But Livorno was a city strongly characterized by multilingualism, also in virtue of the many foreign communities, the largest of which were the Jewish ones. Speaking of the women of Livorno with their mother, Boucher made some linguistic considerations, describing the Jewish female community: « Il y a, d'ailleurs, des femmes agréables à Livourne. Je n'y comprends pas les Juives qui sont plus qu'agréables : elles sont belles. Malheureusement elles ne parlent qu'hébreu, si toutefois elles parlent "[xvi]. In the city, therefore, Hebrew was spoken, but also Arabic, Spanish, Armenian, English and many other languages (Franceschini, 2009).

\section{The end of Boucher's journey in Italy}

In 1809 the former Roman states were annexed to the Empire, so there was a need to organize the entire customs system. Thereby, for the experience gained, Boucher, in March 1810, was sent in Foligno. Foligno, a small city in the actual Umbria, was chief town of a sous-préfecture of the department of Rome, one of the two last Italian departments annexed to the Empire. Newly arrived, he wrote to the Director General of Roman Customs, Jean Baptiste Collin de Sussy, on 26 March 1810, about the composition of the customs offices in Foligno:

" Le personnel de ma division semble avoir été recruté sous la tour de Babel: Provençaux, Corses, Piémontais, Génois, Toscans, Romains, etc., disertori, bravi, sbirrie qualche cosa di meglio, birbanti, assassini, [sic] tel est le noyau de mon régiment; tous agneaux moins propres à se laisser manger que disposés à manger les autres : grande qualité dans notre position, car sans la peur qu'ils inspirent, peur assez bien fondée, nous aurions peut-être été tous égorgés »[xvii]. 
The variety of origins had to create a certain linguistic confusion, rendered well by the analogy of the Tower of Babel. However, in Foligno, Boucher, does not make as many observations on language practises as in Genoa or Livorno. Foligno was then a small town, not very cultured and quite far from Rome, but now Boucher, after five years spent in Italy, seems used to the language spoken by the local population, with whom he spoke in his Italian:

«Il y a, dans la maison où je demeure, deux petites demoiselles, un gros papa, une plus grosse maman et un fraticello, ne sachant pas à eux tous un mot de français; aussi, je leur parle mon italien picard, qu'ils entendent comme ils peuvent. N'étant jamais sortis de leur pays, tout ce qui est étranger leur semble extraordinaire. Ils me font sur la France des questions si naïves, que j'ai peine à ne pas rire, car rien de plus simple qu'un Italien quand il est simple $»$ [xviii].

Boucher spoke in Italian with his Picardesque accent, not fully understood by the local population. If Boucher had gotten used to the local practises, also in Foligno, city where «il passe tant d'étrangers», the common people had gotten used to the French. In this regard, in a letter to the mother concerning the girls of the place (the usual topic between Boucher and his mother) he reported this episode: «L'autre jour, l'une d'elles désirait savoir mon nom. Je faisais semblant de ne pas vouloir le lui dire. Elle n'en insistait que plus. Tout d'un coup elle cesse de me le demander et me dit: Lo so il suo nome. Egli si chiama monsu come tutti gli altri franzezi»[xix]. The way in which the Umbrian girl cut short Boucher's capricious hesitation shows a certain resignation of the local population towards the French: after all, they were all "monsu", monseigneurs.

\section{Boucher's linguistic observations}

In the testimonies seen so far, the impressive thing is the emphasis placed by Boucher on linguistic practices or repeated references to issues concerning languages and dialects. During his stay in Livorno, for example, Boucher had made some trips to Corsica, which could be reached in a short time from the port of Livorno. From here he noted with a certain contempt:

« Les Corses se flattent d'avoir une langue à eux, une langue corse; mais ce n'est qu'un patois mêlé d'italien, de génois et de français. Il y a un coin de l'île dont le dialecte est du grec corrompu. En général, les paysans corses sont sobres de paroles, différant en cela des Italiens[xx]».

Apart from the observation on the Italian loquacity, the attention to the linguistic data can be due to the fact that at the time the mixture of peoples and languages had to create a strong impression in the people, and the repeated perception of the linguistic differences was normal and inevitable. In addition to the difficulties of understanding, among the letters of Boucher emerged the amusement of hearing unexpected words spoken in local dialects. In the customs offices, Boucher had also come into contact with the dialects of large parts of the Italian peninsula and beyond. Here an example referred to Foligno:

" J'en aurais long à vous dire, si je vous répétais tous les propos, tous les lazzis qui sortent de tant de bouches, en provençal, en toscan, en génois, en napolitain, en corse, en romain, en piémontais. Il y a un de ces derniers qui n'ouvre jamais la sienne sans qu'on n'éclate de rire ; il parle le patois de Gérolomo ou Jean-andouille le loustic des 
marionnettes [mask known today by the name of Gianduia]. Je ne comprends que la moitié de ce qu'il dit, et j'aurais grande peine à vous le traduire ».

In addition to the Provençals and the Corsicans, Boucher enjoyed listening to the dialects of Tuscans, Genoese, Neapolitans, Romans and Piedmontese. Of these last, Boucher tells of an individual who spoke in a Piedmontese dialect similar to that used by the theatrical mask of Gérolamo, very famous then in all Italy, that Boucher might have heard in Genoa. However, "lorsque le vent tourne à la France ", an interesting fact portrayed by Boucher is the increasingly diffusion of the knowledge of French: a fact of which he has the confirmation in Genoa and in Livorno. From Genoa Boucher had replied to his mother about a letter in French received by the latter from an Italian friend of his son:

«Vous êtes étonnée du bon style de la lettre que vous a écrite Mme $\mathrm{S}^{* * *}$. Ce n'est pas chose rare à Gênes, et plusieurs dames génoises écrivent le français mieux que bien des Françaises. Voici le billet que je recevais hier de Mme Argentine Spinola, aujourd'hui sur le retour, mais sa beauté et son esprit ont survécu aux années : " Monsieur, faites-moi le plaisir de venir dîner mardi chez moi. Quoique ceci en vaille peu la peine, je m'y prends d'avance, car tant de personnes désirent vous avoir, que probablement je ne vous aurais pas si je m'y prenais plus tard[xxi] ».

From Livorno Boucher reported a similar episode:

« Je vous parlais un jour du style épistolaire des Italiens et Italiennes: en Toscane, comme à Gênes, les femmes manquent généralement d'instruction, mais malgré cela, et peut-être à cause de cela, leurs lettres sont charmantes. En voici encore un exemple : c'est une invitation au bal»[xxii].

31 Boucher attached to this letter the invitation of a lady from Livorno in French. So, although Boucher says that generally Tuscan women lacked education, this Tuscan lady knew how to write in French. This is because the widespread practice of learning French was a growing phenomenon not only among the Genoese or Tuscan elite, because knowing this language gave access to positions in the new French administration.

\section{Conclusions}

Regarding the Italian population, Boucher can do nothing other than point out on several occasions that people of every social class spoke local dialects rather than Italian, a fact confirmed also by Coqueberts. However, the French occupation was triggering mechanisms that, in the long run, would have changed the linguistic habits of the Italian departments, but which the brevity of Napoleonic domination had not allowed. If in this article I have not been able to draw for whole the linguistic geography of Napoleonic Italy, I believe that at least have emerged some cues that permit to comprehend the Italian linguistic variety.

The personal experience of Boucher de Perthes represents a unique testimony of a path that many French did during the Napoleonic era in Italy. Moving between the various departments of the Napoleonic Empire many officials and soldiers often changed territory and consequently often found themselves in places different for traditions, customs and, above all, for language. Boucher during his journey witnessed the spatial dimension of the First Empire in Italy, but also provides a special and unique point of view on the perception of Italian linguistic practices. In accordance with the 
perspective described in Coqueberts' surveys, these demonstrations give the idea of the language spoken by the people, on which it is often difficult to have information.

To conclude, Boucher's letters show an Italy divided between the persistence of regional dialects and the clash between French and Italian cultures and languages. The Italians were left only with a resigned and weak form of resistance to the French power: that of the refusal to speak French. As reported by Boucher, that was the method used by pope Pius VII, prisoner in Savona of the French government:

"Pie VII est un homme simple et bon, et qui supporte son malheur avec une patience angélique. Quoiqu'il sache le français, il ne veut parler qu'italien, peut-être un peu par pique du mal que lui fait la France. C'est la seule vengeance qu'il tire de nous »[xxiii].

[i] Cf. Pour une histoire de la statistique, tome 1, Contributions, Paris, INSEE, Economica, 1990.

[ii] Galimard, 1992, p. 54.

[iii] Ködel, S., 2014, Textes et index pour servir d'introduction au Corpus Coquebert de Montbret, in Die Enquête Coquebert de Montbret (1806-1812), Bamberg, University of Bamberg Press, p. 220.

[iv] Cf. « Bicentenaire de la naissance de Jacques Boucher de Perthes "père de la préhistoire" et fonctionnaire des douanes 1788-1988 », in Les cahiers d'histoire des douanes français, special number, $n^{\circ} 6,1988$.

[v] Jacques Boucher de Perthes, Sous dix rois. Souvenirs de 1791 à 1860, 8 voll., Paris, Jung-Treuttel et Dumoulin, 1863-1868.

[vi] Jean Tulard describes the source of Boucher as reliable in : Jean Tulard, 1971, Bibliographie critique des mémoires sur le Consulat et l'Empire écrits ou traduits en français, Genève-Paris, Libraire Droz, p. 258.

[vii] Jacques Boucher de Perthes,1863, Sous dix rois. Souvenirs de 1791 à 1860, vol. I, Paris, JungTreuttel et Dumoulin, p. 201-202.

[viii] Ibidem, p. 208.

[ix] Ibidem, p. 333.

[x] Ibidem, p. 279.

[xi] Ibidem, p. 422.

[xii] Ibidem, p. 353.

[xiii] Ibidem, p. 253.

[xiv] Ibidem, p. 407.

$[\mathrm{xv}]$ Ibidem, p. 460.

[xvi] Ibidem, p. 461.

[xvii] Jacques Boucher de Perthes, 1863, Sous dix rois. Souvenirs de 1791 à 1860, vol. II, p. 39.

[xviii] Ibidem, p. 57.

[xix] Ibidem, p. 56.

[xx] Ibidem, p. 543.

[xxi] Ibidem, p. 392.

[xxii] Ibidem, p. 21. 
[xxiii] Jacques Boucher, op. cit., vol. I, p. 561.

\section{BIBLIOGRAPHY}

\section{Bibliographie}

Broers M., 2003, « The Myth and Reality of Italian Regionalism: A Historical Geography of Napoleonic Italy, 1801-1814 », The American Historical Review, Volume 108, n 3, p. 688-709.

Franceschini F., 2009, « Le plurilinguisme à Livourne. Reflets dans la littérature dialectale à la fin du dixhuitième-siècle et dans la première moitié du dix-neuvième siècle », in Nonnoi G., Circolazione di idee, parole, uomini, libri e culture. Sardegna, Corsica, Toscana, Cagliari, CUEUC, p. 147-166.

Galimard K., 1992, «L'enquête, l'enquêteur, l'enquêté (le témoin) », Langue française, n93, p. 53-73.

Ködel S., 2014, Die Enquête Coquebert de Montbret (1806-1812). Die Sprachen und Dialekte Frankreichs und die Wahrnehmung der französischen Sprachlandschaft während des Ersten Kaiserreichs, Bamberg, University of Bamberg Press, $626 \mathrm{p}$.

McCain S., 2018, The language question under Napoleon, Basingstoke, Palgrave Macmillian, 307 p.

\section{ABSTRACTS}

The territorial expansion of the First Napoleonic Empire and the mobility of French soldiers and officials created the conditions for bringing together people of different nationalities and languages. In Italy, the many French serving Napoleon clashed with local linguistic habits, in which each city had its own dialect to the detriment of Italian. Jacques Boucher de Perthes, who is considered one of the fathers of the prehistoric sciences, was employed in the imperial customs in Italy and through his correspondence, he described the linguistic practices of the cities in which he served, Genoa, Livorno and Foligno, and the territories surrounding them. He noted that the dialects were spoken in all social classes and were different from city to city. His letters represent a unique source for the description of the linguistic geography of Italy at the time, which testifies to the Italian linguistic variety. In addition, Jacques Boucher de Perthes describe the oral practices, on which it is often difficult to find sources.

L'expansion territoriale du Premier Empire napoléonien et la mobilité des soldats et des fonctionnaires français créent les conditions d'un rapprochement des peuples de nationalités et de langues différentes. En Italie, les nombreux Français qui servaient Napoléon se heurtaient aux pratiques linguistiques locales, où chaque ville avait son propre dialecte au détriment de l'italien. Jacques Boucher de Perthes, considéré comme l'un des pères des sciences préhistoriques, fut employé par les douanes impériales en Italie et, dans sa correspondance, il décrit les pratiques linguistiques des villes où il travaillait, Gênes, Livourne et Foligno et des territoires qui les 
entouraient. Il a noté que les dialectes étaient parlés dans toutes les classes sociales et étaient différents d'une ville à l'autre. Ses lettres représentent une source unique pour la description de la géographie linguistique de l'Italie de l'époque, qui témoigne de la variété linguistique italienne. En outre, Jacques Boucher de Perthes décrit les pratiques orales, pour lesquelles il est souvent difficile de trouver des sources.

\section{INDEX}

Mots-clés: géographie linguistique, premier empire napoléonien, départements annexés italiens, pratiques orales, dialectes

Keywords: linguistic geography, First Napoleonic Empire, Italian annexed departements, oral practices, dialects

\section{AUTHOR}

\section{ELISA BACCINI}

University of Padua - Université de Padoue 